\title{
Librarian E-Readiness in the Disruption 4.0 Era
}

\author{
Surya Adi Sasmita ${ }^{1}$ \\ ${ }^{1}$ Universitas Terbuka, Tangerang Selatan, Banten, Indonesia \\ e-mail: suryaadisasmita@ecampus.ut.ac.id
}

\begin{abstract}
Article Info
Article history:

Received

May $12^{\text {th }}, 2021$

Revised

July $19^{\text {th }}, 2021$

Accepted

July $26^{\text {th }}, 2021$

Published

July $30^{\text {th }}, 2021$

Abstract

In the era of disruption of the industrial revolution 4.0 as it is today, there are almost no difficulties in meeting information needs. Both information that is educational or information that is entertainment. A librarian is a profession whose job is to provide and present information to its users. how is the level of readiness of higher education librarians in the era of disruption including what factors affect the readiness of librarians and how librarians adjust to the era of disruption 4.0. In this study using themethod Quantitative Research. This method was chosen by the author because the author wanted to know the level of readiness to implement the development of information technology with the basis or tools on the model developed by $\mathrm{Mu}$ tula and Brakel. E Readiness, shows a value of 3.393. The value can mean "Ready". This average calculation is obtained from the average results for each sub-indicator which then becomes the value for each segment or indicator and then is averaged again to find the value of readiness information for the era of disruption 4.0.
\end{abstract}

Keywords: e-readiness; disruption; librarian

\begin{tabular}{l} 
Abstrak \\
\hline Pada era disrupsi revolusi industri 4.0 seperti saat ini, hampir tidak ada kesu- \\
litan dalam hal pemenuhan kebutuhan informasi. Baik informasi yang bersifat \\
pendidikan ataupun informasi yang bersifat hiburan. Pustakawan salah satu pro- \\
fesi yang bertugas menyediakan dan menyajikan informasi bagi penggunanya. \\
bagaimana tingkat kesiapan pustakawan peguruan tinggi dalam era disrupsi \\
termasuk faktor apa saja yang mempengaruhi kesiapan dari pustakawan dan \\
bagaimana pustakawan dalam menyesuaikan diri dalam era disrupsi 4.0. Dalam \\
penelitian ini menggunakan metode Quantitative Research. Metode ini dipilih \\
penulis karena penulis ingin mengetahui tingkat kesiapan implementasi perkem- \\
bangan teknologi informasi dengan dasar atau tool pada model yang dikembang- \\
kan mutula dan brakel. E Readiness, menunjukan nilai 3,393. Nilai tersebut dapat \\
berarti "Siap". Perhitungan rata - rata ini didapatkan dari hasil rata - rata pada \\
setiap sub indikator yang kemudian menjadi nilai pada setiap segmen atau indi- \\
kator dan kemudian di rata - rata kembali untuk menemukan nilai keterangan \\
kesiapan terhadap era disrupsi 4.0.
\end{tabular}

Kata Kunci: kesiapan elektronik; gangguan; pustakawan 


\section{INTRODUCTION}

Along with the development of information technology, a globalization is created which is marked by an information explosion. The development of this information was initiated by the development of supporting tools or what we know as "Gadgets". There are many tools that we can use and access through a network that makes the information spread so much and we receive it quickly. Ease of accessing information without being limited by distance, space, and time is one of the mainstays in the current era. Too easy and the amount of information circulating makes us have to be able to choose, sort, and manage information that can really be accounted for and information that is only a passing wind or temporary reading.

In the era of disruption of the industrial revolution 4.0 as it is today, there are almost no difficulties in meeting information needs. Both information that is educational or information that is entertainment. Information also takes various forms, both in the form of writing to information in the form of videos, we can easily get. In this era of information dissemination, there are many things in life that must change in order to continue to exist and not be eroded by the times. Self-adjustment and capacity building need to be done so as not to be left behind and always efficient. One of the professions engaged in the field of information and must really need to adapt to the conditions of this era of disruption is a librarian.

A librarian is a profession whose job is to provide and present information to its users. This profession is very instrumental in helping the learning process and the process of fulfilling the information needed by users. Librarians must have expertise in selecting useful information for users. Capabilities need to be adjusted along with the development of the era of disruption of the industrial revolution 4.0 as it is today. With busy services in the library, librarians are required to follow the development of the era of disruption of the industrial revolution 4.0 in order to serve users in meeting the information needs of users. Users who use a lot of information in terms of fulfilling information needs that can be accounted for.

Higher education is one level of education that requires updated, valid, and accountable information. Information used by the academic community is used to deepen academic theory and knowledge or in terms of implementing the tri dharma of higher education. This librarian profession must be able to serve the needs of users, namely the heterogeneous academic community. The librarian profession at universities is very much required to have readiness for various rapid developments in information technology. This is because university librarians are the focus in finding information for the academic community.

In the last decade, the development of information is extraordinary, so much information is all around us. However, only information that comes from trusted sources can be used by the academic community. The information provided by the librarian is not only printed but also digital, considering that in this era of disruption, a person can easily and quickly meet the information needs they need. It is hoped that distance higher education librarians will be able to follow the development of the era of disruption of the industrial revolution 4.0 in providing information to users. Therefore, it is necessary to prepare and familiarize librarians with the use of technology so that librarians can continue to serve users even though it is a variety of information.

We need to pay attention to the readiness of librarians in facing the era of disruption 4.0. So that librarians can continue to serve the information needs of library users. According to the book from Prof. Renald Kasali (2017) entitled "Disruption", one of the professions that will be lost in the future is librarian. This is because it is easier to find information. To anticipate this, we need to know the extent of the readiness of librarians in facing the era of disruption 4.0. Many factors support the readiness of librarians to face this disruption. The extent to which the readiness of librarians in facing this era of disruption.

In this paper, it will be explained how the level of readiness of higher education librarians in the era of disruption includes what factors affect the readiness of librarians and how librarians adjust to the era of disruption 4.0.

\section{METHOD}

In this study using the method of Quantitative Research.InabookentitledResearchDesign:Qualitative, Quantitative, and Mix Methods Approach written by Creswell (2009), explains that quantitative research is a method of investigation to identify problems based on testing a theory that can be measured by numbers and analysis using statistical techniques. . This method was chosen by the author because the author wanted to know the level of readiness to implement the development of information technology with the basis or tools on the model developed by Mutula and Brakel. This quantitative method is considered suitable for research because it uses numerical data.

The population and samples that the writer uses are several university librarians in Yogyakarta. 
Yogyakarta was chosen because it is known as the City of Students, so it has many public and private universities. Test the validity and reliability of the questionnaire instrument used using Product Moment and Cronbach Alpha which was calculated using the SPSS program. Assessment of the level of readiness of the indicators is calculated through thevalue Mean (average) of the questionnaire scores. The calculation of the Range Score is as follows:

Table 1. Range Score E Readiness

\begin{tabular}{ccc}
\hline Score & Category & Explanatiom \\
\hline $3,41-4,00$ & Level 5 & Very Ready \\
$2,81-3,40$ & Level 4 & Ready \\
$2,21-2,80$ & Level 3 & Less Ready \\
$1,61-2,20$ & Level 2 & Not Siap \\
$1,00-1,60$ & Level 1 & Very Not Ready \\
\hline
\end{tabular}

\section{RESULTS AND DISCUSSION}

The College Library is a library that is used to support the activities of the academic community which aims to implement the Tri Dharma of Higher Education. With the development of information technology, which is characterized by the ease of finding information using modern tools, there will be a lot of information or what is called an information explosion. It also requires libraries to also apply adequate equipment in accordance with the times. Libraries that apply the development of information technology must also have readiness in their operations. E Readiness in the library can be interpreted as a readiness of library institutions in utilizing information technology to provide maximum information services to library users. If the library applies information technology in service,needed $E$ Readiness is from the librarian as the library manager.

The model for implementing E Readiness is based on $E$ Readiness for librarians in terms of following the direction of development in the Disruption 4.0 era which is used in services as a form of organizing libraries. The model used by the author is "An Integration Information Rich E Readiness Assessment Tools which is the development of severalconcepts E Readiness developed by Mutula and Braker in 2006 by adding an indicator of information access components in this model. This model is used because it assesses the readiness of an institution in terms of progress towards access to information. There are 5 segments or indicators in this model, namely: Enterprise Readiness, Human Resources Readiness, Infrastructure Readiness, Information Readiness, External Invorenment Readiness. Each segment or indicator has several sub-indicators that are used as assessment material. Each segment or indicator has a different number of sub-indicators that have been developed by the author.

\section{Enterprise Readiness}

This segment or indicator measures the readiness of library institutions in implementing information technology as service access to library users.

Based on the results of the questionnaire calculation, that institutional readiness for the application of information technology in the era of disruption is included in the "Ready" category. This enterprise readiness is strongly influenced by the readiness of library institutions to advances in technology and developments in the era of disruption

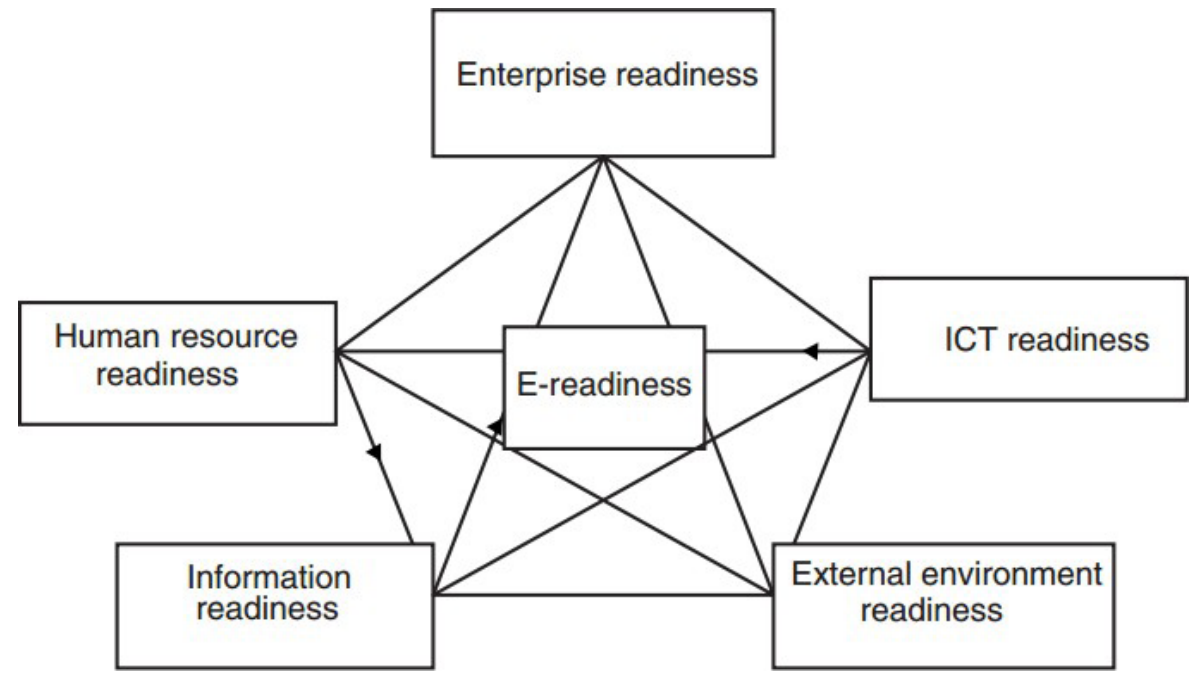

Figure 1. Assessment Pictures Readiness Mutula and Brakel 
Table 2. Enterprise Readiness

\begin{tabular}{llc}
\hline \multicolumn{1}{c}{ Indicator } & \multicolumn{1}{c}{ Sub Indicator } & $\begin{array}{c}\text { Indicator } \\
\text { Value }\end{array}$ \\
\hline & Your library has a good information technology implementation & 3,351 \\
& procedure & \\
& Your library has an information management department & 3,072 \\
& Your library has a strategic plan in the field of information technology & 3,522 \\
Enterprise Readiness & All information technology in the library is of international standard & 3,441 \\
& Your library has sufficient budget for the development of information & 3,392 \\
& technology in the library & \\
& Your Library Leader always gives initiation to use information & 3,118 \\
& technology in library services & 3,316 \\
\hline
\end{tabular}

4.0. This requires the awareness of all library managers and librarians in terms of improving the quality of services that adapt to the rapid progress of information technology development. The role of all parties in the library is very decisive in the progress of the library adapting to the era of disruption 4.0.

The awareness of all library managers and librarians will determine whether the library is ready or not in adjusting or adapting to the rapid development of information technology. The strength and common vision and mission of managers and librarians will lead to the direction of library development. Of course all of this requires awareness and support from the leadership and the strength of the library budget. The policy direction of the library leadership is very decisive in the readiness of the library in adapting to the era of information technology development. The availability of an adequate budget is also a dominant factor in the development of libraries. The need for an adequate budget will also determine how much institutional readiness to adapt to the development of the 4.0 disruption era

\section{Human Resources Readiness}

This segment or indicator measures the readiness of human resources in the library. The readiness of human resources is important because it is the driving force for library operations. Based on the results of the analysis on the indicators of the readiness of human resources for the application of information technology in the era of disruption, it falls into the "Very Ready" category. Readiness of the librarian is indispensable in readiness welcome the era of disruption 4.0. Librarians are required to always improve their abilities to keep up with the rapid development of information technology. Librarians must be at the forefront of understanding advances in information technology that will be useful in terms of information services to users. Improving self-ability must always be done by librarians so that librarians always serve users by providing services that are adapted to the development of information technology.

Improving the ability of librarians can be done through various ways. Even in this era of disruption 4.0, librarians can improve their own abilities. Improving the ability of librarians can be through training, training, workshops, or through activities held by existing professional organizations. In addition, librarians can improve themselves through videos that are spread through social media. Librarians can also improve themselves by reading

Table 3. Human Resources Readiness

\begin{tabular}{llc}
\hline Indicator & \multicolumn{1}{c}{ Sub Indicator } & $\begin{array}{c}\text { Indicator } \\
\text { Value R }\end{array}$ \\
\hline Human Resources & You are aware of the importance of information technology in libraries & 3,782 \\
Readiness & Your library has information technology staff with diverse educational & 2,941 \\
& backgrounds & \\
& You have good skills in using information technology in library service & 3,815 \\
& Your library has reliable information technology staff & 3,550 \\
& You have the ability in managing information well & 3,477 \\
& You have the ability to analyze information well & 3,861 \\
\hline & \multicolumn{2}{c}{ Average } \\
\hline
\end{tabular}


more. Although the librarian is tasked with serving information to the users, the librarian also needs to read, try, and practice a lot, which aims to improve his or her abilities so that they can adapt to the rapid development of information technology.

\section{Infrastructure Readiness}

In this indicator of infrastructure readiness, the readiness of libraries in the field of implementing or implementing information technology will be assessed as a measure of the progress of services based on information technology. In this Infrastructure Readiness, it has a readiness value of 3,356 which means it has a "Ready" category. Readiness of infrastructure also affects the readiness of libraries in general in the face of the disruption of information technology 4.0. The use of tools in library services such as computers and several other tools is very influential in the quality of library services that adapt to the development of information technology. How can a library adjust or adapt to the development of information technology if the equipment used is still classified as conventional or out of date equipment. The use of tools that are in accordance with the development of the era of information technology development can be a benchmark whether or not the library is ready to serve users in accordance with the development of the era of disruption 4.0.
Internet connection has also become one of the factors in the infrastructure supporting the library's readiness to face future developments in information technology disruption 4.0. Although currently an internet connection is not a rare item in the world of education, there are some libraries that are not yet optimal in providing internet connections as service access for users. Internet connection speed is sometimes still an obstacle in the administration of the library. It can be a low value of infrastructure readiness in the library. The speed of internet service connection in the library can be a support that the library is ready to follow the direction of the development of disruption 4.0

\section{Information Readiness}

In this section will be assessed on the readiness of libraries in providing information to users. Based on the results of the analysis on the indicators of readiness of information in the library on the application of information technology in the era of disruption, it falls into the category of "Very Ready". Many libraries that have not implemented security procedures in accessing information. This is because at least there are libraries that have standard operational procedures on security of access to information and standard operational procedures on backing up data managed by libraries. In the era of information

Table 4. Infrastructure Readiness

\begin{tabular}{clc}
\hline Indicator & \multicolumn{1}{c}{ Sub Indicator } & $\begin{array}{c}\text { Value } \\
\text { Indicator }\end{array}$ \\
\hline \multirow{4}{*}{ Infrastructure } & Internet connection in your library is very fast & 3,509 \\
Readiness & All work units in the library already use information technology & 3,171 \\
& computer you use for work can be connected to other computers (sharing) & 3,412 \\
& Your library has a good website as a means of publication & 3,031 \\
& Online access your library is very secure & 3,528 \\
& The network connection in your library is very good & 3,483 \\
\hline \multicolumn{2}{c}{ Average } & 3,356 \\
\hline
\end{tabular}

Table 5. Information Readiness

\begin{tabular}{clc}
\hline Indicator & \multicolumn{1}{c}{ Sub Indicator } & $\begin{array}{c}\text { Value } \\
\text { Indicator }\end{array}$ \\
\cline { 2 - 3 } & Your library provides all the information that users need & 3,627 \\
& library has a good information storage infrastructure (server) & 3,108 \\
Information & library has a good backup procedure & 3,027 \\
Readiness & Information Accessing in the library is very easy & 3,614 \\
& library has a good mechanism for collecting, storing and retrieval of good & 3,591 \\
& information & \\
& Libraries can provide information from inside and outside the library & 3,738 \\
\hline & \multicolumn{2}{c}{ Average } \\
\hline
\end{tabular}


technology development, everything seems easy, but security access and procedures for backing up data are needed. This is done so that when an unexpected problem or accident occurs, the library does not lose existing information data.

Adapting to the development of information technology, libraries should have implemented standard operational procedures in terms of backing up data security. Besides that, the most important thing is how the library prepares risk management from the application of information technology in information services to users. The application of risk management in library operations can anticipate risks that will arise due to system errors or loss of information data. The application of risk management needs to be applied in the library as a data protection information in the library. This risk management needs to exist because in the implementation of the development of information technology there will always be obstacles, therefore it is necessary to anticipate from the start with the application of risk management.

\section{External Environmental Readiness}

In parts of these indicators will be assessed to external factors facing the era of readiness disrupsi 4.0 . Based on the analysis on indicators of readiness External Environment in the library of the application of information technology in the era of disruption into the category of "Ready". Readiness from external parties will also affect the readiness of libraries to face the era of disruption 4.0. The external party is like the highest leader in an institution that is the shade of the library. In this case, it is the highest leadership in the campus or government. Policy support from the leadership of the institution or government will also determine the direction of library development. The need for awareness from external parties to develop libraries in accordance with the development of information technology so that libraries are not left behind by the era that is growing rapidly.

Some of the data described above is an analysis of each - each segment or indicator of E Readiness taken the average - average or mean the of sub indicator. The following are the results of themodel analysis E Readiness overall:

Table 6. External Environmental Readiness

\begin{tabular}{clc}
\hline Indicator & \multicolumn{1}{c}{ Sub Indicator } & Value \\
\hline & The providers used are of very good quality. & 3,458 \\
External & The government or leadership is very supportive of the development of information & 3,016 \\
technology in the library & \\
Invorenment & All information technology infrastructure is in accordance with national standards & 3,327 \\
Readiness & There is a policy in every work unit in the library & 3,081 \\
& The electricity supply in the library is very adequate & 3,502 \\
& Has software or applications that run smoothly and rarely have errors & 3,238 \\
\hline & Average & 3,270 \\
\hline
\end{tabular}

Tabel 7. E Readiness Score

\begin{tabular}{cc}
\hline Indicator & Value \\
\hline Enterprise Readiness & 3,316 \\
Human Resources Readiness & 3,571 \\
Infrastructure Readiness & 3,356 \\
Information Readiness & 3,451 \\
External Environmental Readiness & 3,270 \\
\hline Average & 3,393 \\
\hline
\end{tabular}

Based on the information from Table 7 about thescore E Readiness, it shows a value of 3.393. The value can mean "Ready". This average calculation is obtained from the average results for each subindicator which then becomes the value for each segment or indicator and then is averaged again to find the value of readiness information for the era of disruption 4.0.
In accordance with the calculation of the average E Readiness globally, it can be concluded that broadly speaking, librarians at universities are ready to implement information technologybased services in libraries in the Disruption 4.0 era. Although the indicator value refers to the ready level, the librarian should try more to improve the indicator level and the librarian must always be ready to face the rapid development or advancement of information technology. Librarians must be ready and alert to become information gates for the academic community or library users. This is so that the library is not left behind with advances in information technology used in finding information.

In order for librarians to be more prepared or feel very prepared in the face of increasingly rapid technological developments, training or workshops 
are needed that aim to improve the capabilities of librarians. So that librarians are not left behind by the development of existing information technology. This is also related to the existence of a library budget that is used for library service operations and to improve services and improve the capabilities of librarians.

In addition to budget support, the most important thing for the readiness of librarians and libraries in serving information is support from leaders. The policy direction taken by the leader must be in line with the progress of the quality and readiness of libraries and librarians. If the policy direction from the leader does not support librarians and libraries to develop, it is certain that the library will not last long due to the rapid development of information eroded. In addition to the policy direction, how a leader can manage the library well, change a conventional library into a digital library by following the direction of the times.

In the era of Disruption 4.0, library leaders and librarians are indeed needed who are reliable in managing libraries so that libraries are not lost to the development of the times. There needs to be an update in the library and in the world of librarianship so that the library still exists and can serve the information needs of its users.

Placement of personnel or employees in the library also needs to be considered. To maximize services in the library, it is necessary to have people who are experts in the field of information technology or people who are experts in librarianship. The library is not a place for outcasts or people with special training for violating discipline. However, the library is an information center whose information content can be accounted for.

\section{CONCLUSION}

In improving the readiness of librarians and libraries in providing information to users, special attention from the leadership is needed. There needs to be a different policy and management or management so that the library can still exist and serve its users. Increased capability in librarians is needed so that librarians in managing libraries can be optimal and always follow the times. Even though according to the data currently available, university librarians are considered ready in terms of facing the era of disruption 4.0, but if they do not increase their abilities or capabilities, they will gradually be eroded by the development of information technology which will make it easier for people to access information.

\section{REFERENCES}

Bowles, D.M.,(2011) “E-Readiness Audit Tool”, Australian Maritime College Department of Maritime and Logistic Management University of Tasmania Launceston,

Bui et.al, Dalam Matuka CKJ Bwalya, “Assesing E-Readiness of the Copperbelt University, Zambia: Case Study", The International Journal of Information Learning Technology.,V.33 Iss.5. Dalam: http://dx.doi. org/10.1108/IJILT- 12-2015-0036

Creswell, J. W. (2009). Research Design: Qualitative, Quantitative, and Mixed Methods Approaches. Lincoln, Nebraska: SAGE Publications, Inc.

Kasali, Rhenald. (2017). "DISRUPTION", Jakarta : Gramedia Pustaka.

Muafi, Gusaptono, H., Effendi, M. I., \& Charibaldi, N. (2012). The Information Technology (IT) Adoption Process and E- Readiness to Use within Yogyakarta Indonesian Small Medium Enterprises (SME). International Journal of Information and Communication Technology Research, 29-37.

Mutula, Stephen M. \& Peter Van Brakel, "An Evaluation of E-Readiness Assessment Tools with Respect to Information Access: Towards an Integrated Information Rich Tool" International Journal of Information Management 26,2006, Dalam http:// www.sciencedirect.com/science/article/pii/ $\underline{\mathrm{S} 0268401206000077}$

Nugroho, P. D. (2010). Analisis E-Readiness di Instansi Pemerintah: Studi kasus Departemen Luar Negeri Republik Indonesia. Jakarta: Universitas Indonesia.

Parasuraman, A. (2000). Technology Readiness Index (Tri): A Multiple-Item Scale to Measure Readiness to Embrace New Technologies. Journal of Service Research, 307.

Pendit, Putu Laxman, (2008.) Perpustakaan Digital dari A sampai $Z$, Jakarta: Cita Karyakarsa Mandiri:

Walczuch, R., Lemmink, J., \& Streukens, S. (2007). The effect of service employees' technology readiness on technology acceptance. Science Direct, 206 - 215. 